\title{
Students' Transition from Secondary School French Programs into University Level French Immersion
}

\author{
Jérémie Séror \\ University of Ottawa \\ Alysse Weinberg \\ University of Ottawa
}

\begin{abstract}
A great deal of time and resources are invested throughout Canada to encourage students to learn French as a second official language through a variety of programs (core French, intensive French, and French immersion programs). Little is known, however, about the impact of these efforts once French language learners complete their high school studies. This paper reports on longitudinal qualitative case studies of two students registered within a Canadian university-level immersion stream. Drawing on an academic discourse socialization approach, the paper examines students' perspectives of their literacy development as they transition from high school French language programs to a universitylevel immersion program designed to promote advanced levels of bilingualism. Findings stress how the experience of transitioning from French high school programs to university immersion challenges students' perception of themselves as French learners and their notion of the legitimacy of their high school French experiences.
\end{abstract}

\section{Résumé}

Au Canada, les différents paliers éducatifs investissent un montant considérable de temps et de ressources pour encourager des élèves à apprendre le français comme deuxième langue officielle grâce à divers programmes (français de base, français intensif et programmes d'immersion française). Cependant peu de recherches se sont penchées sur l'impact de ces efforts une fois que les apprenants de français terminent leurs études au secondaire. Cet article présente une étude de cas qualitative longitudinale portant sur deux étudiantes inscrites dans un programme d'immersion offert dans une université canadienne. En s'appuyant sur une approche de socialisation du discours académique, l'article examine la perspective et le positionnement des étudiantes en ce qui a trait au développement de leurs habiletés langagières alors qu'elles font la transition entre des programmes de français au secondaire vers un programme d'immersion universitaire conçu pour promouvoir des niveaux avancés de bilinguisme. Les résultats soulignent comment l'expérience de la transition entre les programmes de français du secondaire vers l'immersion universitaire remet en question la perception que les étudiants ont d'elles-mêmes en tant qu'apprenantes du français et leurs notions de la légitimité des programmes de français au secondaire. 


\section{Students' Transition from Secondary School French Programs into University Level French Immersion}

In Canada, a long tradition of research on immersion programs in public schools has highlighted the benefits of content-based language learning approaches (Genesee \& Lindholm-Leary, 2013; Lyster \& Tedick, 2014; Swain \& Johnson, 1997). This innovative approach to French second language learning, first developed in 1965 (Lambert \& Tucker, 1972), was among the first formal public school program of its kind to adopt an integrated approach to language and content development for second language acquisition (Brinton et al., 2003; Cammarata, 2016). These programs were designed to immerse Anglophone students in the target language (French) by teaching content courses predominantly in French in elementary schools and selectively in secondary schools.

Research on the educational outcomes of this immersion approach suggests that these programs align themselves well with Canada's commitment to the promotion of opportunities for students to effectively learn their second official language (Government of Canada, 2018). The immersion approach has also been shown to lead to "significant linguistic, academic, and cognitive benefits" (Lazaruk, 2007, p. 606). Indeed, a wide body of research supports the effectiveness of immersion programs as a path to bilingualism with positive outcomes in the areas of content (i.e. subject knowledge), functional proficiency in the target language, and intercultural and metalinguistic competences (August et al., 2006; Genesee, 2004; Hermanto, et al. 2012; Lindholm-Leary \& Borsato, 2006; Mejía, 2008; Séror \& Weinberg, 2012).

These findings have generated a great deal of interest in immersion approaches and have helped establish content-based language instruction as a cornerstone of bilingual education programs worldwide. Close to 50 years after the original Canadian immersion experiments, variations of approaches that integrate to varying degrees content and language, frequently with their own unique labels, abound. These include content and language integrated learning (CLIL), dual language instruction, and bilingual education pedagogic initiatives that can be found throughout Europe, Asia, Australia and the United States (Courcy, 2002; Mejía, 2008; Tedick et al. 2011; Wilkinson \& Walsh, 2015) ${ }^{1}$.

Internationally, programs that integrate content and language development have responded to calls for language programs that can foster minority and heritage languages (e.g., the teaching of Spanish in the United States) or help students acquire the multilingual skills required in a globalized world and job market. Echoing findings stemming from the Canadian context, research has highlighted the strengths of programs that integrate language and content development (Cammarata, 2016; Dalton-Puffer, 2011; Marsh \& Frigols Martín, 2012).

In recent years, an important development in the field of content-based language instruction has been a growing interest in the implementation of tertiary level immersion programs. This has been particularly true in Europe following the "Bologna Declaration" (1999) which created a European Higher Education Zone with standardized university diplomas and increased students' mobility. Since the declaration, universities have been strongly encouraged to adopt an integrated curriculum where both disciplinary expertise and proficiency in a second language are valued. In the context of higher education, in particular, CLIL programs have been adopted to help students acquire advanced multilingual repertoires (Smit \& Dafouz, 2012). Students benefit particularly from the 
ability to work with linguistic forms and patterns that are never separated from the actual disciplinary fields and registers with which they are linked (Schleppegrell \& Colombi, 2002). This ultimately promotes not only foreign language acquisition but also content expertise and the ability to negotiate and produce complex texts in diverse academic and professional settings (Byrnes, 2006; Canagarajah \& Jerskey, 2009; Ninnes \& Hellstén, 2005; Schleppegrell \& Colombi, 2002; Smit \& Dafouz, 2012).

Interestingly, university-level immersion programs in Canada have developed at a slower pace than in other regions of the world (Burger \& Chrétien, 2001; Burger et al., 2013; Genessee, 2011; Knoerr et al., 2016; Lyster, 2008; Saul, 2009). Despite Canada's long tradition of elementary and secondary French immersion programs, currently, only a handful of Canadian universities offer the option to complete a university degree through some form of French immersion approach (Cenerelli et al., 2016). An exception to this rule is French teacher education programs that frequently include content courses offered in French (e.g., McGill's Bachelor of Education in immersion pedagogy and University of British Columbia's Master of Education degree in modern language education offered completely in French). The slow but steady development of these university-based immersion approaches aligns itself with calls from Canadian federal institutions to expand post-secondary learning opportunities in French for Canadian students (Fraser, 2016; Office of the Commissioner of Official Languages, 2009).

Investigations focusing on university-level immersion programs provide evidence for their effectiveness (Cammarata \& Tedick, 2012). These programs allow young Canadians to maintain and improve proficiency in French while pursuing a university program of study. They also maximize learners' exposure to authentic communicative situations, texts, and members of the target language community (Séror \& Weinberg, 2012; Wesche \& Skehan, 2002). Nevertheless, due to the scarcity of these programs detailed accounts of the impact of post-secondary approaches in Canada remain limited (for notable exceptions see, Burger et al., 2013; Knoerr et al., 2016; Marshall \& Laghzaoui, 2012; Moore et al.,2015). This work adds new dimensions to the larger body of research that has explored immersion programs in Canadian public schools (e.g., Genessee, 2011; Lyster, 2008, 2015; Mady, 2017) and the practices and beliefs of French immersion educators, students and graduates (e.g., Auger, 2002; Macintyre et al., 2011; Roy, 2010).

This article seeks to contribute to the literature in this area through the presentation of the cases of two students in a tertiary French immersion stream offered at the University of Ottawa which welcomes approximately 350 students annually. This large scale university immersion stream implements an adjunct model (Brinton et al., 2003) whereby students are registered in both a content course and a helper language course specifically designed to support students with the linguistic demands of the content course (e.g., focus on discipline-specific vocabulary and strategies) (Burger \& Weinberg, 2014; Knoerr \& Weinberg, 2013).

\section{Theoretical Framework}

This study adopts an academic socialization framework (Duff, 2010) to explore the case of immersion students registered in the University of Ottawa French immersion stream. This framework seeks to understand the processes, practices, and identity transformations experienced by language learners in university contexts. In higher 
education, studies of academic discourse socialization have enhanced understandings of language learners' progress in university courses within the day-to-day contexts and discourses that make up these students' learning experiences (Morita, 2009; Morita \& Kobayashi, 2008). These studies draw on in-depth analyses of the language-mediated activities that shape students' learning experiences, progress in their programs of study, literacy practices, and disciplinary enculturation in multicultural settings (Casanave, 2002; Cheng, 2014; Duff \& Anderson, 2015; Duff \& Talmy, 2011; Zappa-Hollman \& Duff, 2015).

This framework expands on studies of second language acquisition that have traditionally emphasized the acquisition of grammatical and rhetorical conventions as the result of cognitive processes. Academic discourse socialization deliberately seeks to emphasize and integrate the sociocultural dimension of language learning (Lantolf et al. , 2015) and the socialization processes that guide language use and development (Duff, 2007; Kramsch, 2002; Ochs \& Schieffelin, 2008). This paper builds upon this literature by investigating the interconnections between immersion pedagogy, language development, and students' identity construction and representations of language learning at the University of Ottawa.

\section{Methodology}

\section{Context and Participants}

This paper draws its findings from qualitative case studies of university students registered in the University of Ottawa French immersion stream. In order to produce rich emic descriptions of "the vicarious experiences of the subjects" (Yazan, 2015, p. 139) a multiple case study design (Yin, 2014) was chosen to investigate the attributes and experiences of focal participants.

The University of Ottawa's French immersion stream was first launched in the mid2000s for non-francophone students with an intermediate to advanced knowledge of French. The program welcomes students from across Canada stemming from public school French immersion programs as well as French Intensive programs and Core French programs ${ }^{2}$. By registering in the University of Ottawa French immersion stream, students can continue to study French beyond high school. Students need to complete a language proficiency test designed to help them personalize their program of study. Students are also required to complete a minimum of 42 credits of courses taught in French by choosing from a combination of credited language, content, and adjunct courses taught in French. This approach allows students to build on and improve French language skills acquired prior to entering university. At the end of their studies students who meet the requirements and pass a language certification test, receive a special "immersion" mention on their undergraduate diplomas designed to validate and showcase their proficiency in their second official language once they enter the job market.

Focal participants were recruited in the fall of 2015 through an email sent to all the incoming immersion students by the director of the University of Ottawa French immersion stream. This recruitment method ensured that all students registered in the 2015-2016 French immersion cohort would have the opportunity to participate in the study. In anticipation of the well-known challenges with retention of participants for longitudinal 
studies, all students who showed an interest in participating were included and no exclusion criteria were used. An original cohort of 42 students ( 35 women and 7 men) volunteered and signed consent forms to take part in a longitudinal project designed to collect students' experience over the 4 to 6 years of their undergraduate studies in the University of Ottawa French immersion stream. The cohort of participants reflected the larger population of students registered in the University of Ottawa French immersion stream and included students who had studied French in a variety of French language programs including French immersion, Core French programs, and Intensive French programs (see Appendix A). In 2020, eleven focal participants had completed all stages of the five-year study.

Each case allowed for the study of the long-term impact and theoretical, pedagogical, and policy implications of the University of Ottawa French immersion stream on university students and focused on the following research questions:

1. What are participants' experiences and perspectives over the four to six years of participation in the University of Ottawa French immersion stream?

2. What specific events, practices, and discourses underlie these experiences and perspectives?

3. What are participants' understandings of the University of Ottawa's French immersion stream on their development (linguistic, social, cultural, and identity construction)?

To help build up the cases of each focal participant and answer the research questions, a range of data sources were collected including semi-formal interviews (Merriam, 1998) (one per semester with an average duration of 45 minutes), focus groups (Krueger, 2015), demographic information collected through questionnaires for each of the participants, reflective drawings (language portraits (Molinié, 2009) and language maps (Gohard-Radenkovic, 2016), and copies of relevant textual documents provided by participants (ex. course outlines, samples of course assignments and copies of evaluations). Each data source helped triangulate the findings. The interviews and focus groups ( 1 per semester with an average duration of 45 minutes) allowed students to discuss, in an indepth manner, issues, events, and relationships perceived to have impacted their trajectory as language learners (see Appendix B for examples of questions asked). The reflective drawings (Bemporad \& Vorger, 2014) were designed to visually explore and share their identities and linguistic repertoires through language portraits (Castellotti \& Moore, 2009; Lemaire, 2013) and the overall representation of their language learning trajectory through the language map (Gohard-Radenkovic, 2016). The various data sources were analyzed to arrive at a more complex and precise description of the multiple facets that made up the focal participants' university immersion experience.

\section{Data Analysis}

Interview and focus group data were transcribed with the help of the qualitative data analysis software Transana (Parmeggiani, 2009; Woods \& Dempster, 2011). This software allows transcriptions to be linked to raw audio recordings of the interviews and relevant digital images and textual documents allowing for the creation of multimodal transcripts (Antoniadou, 2017). It was thus possible to read and code the section of the 
transcript where a student laughs about something in her language portrait while listening to the tone of that laughter in the raw recording and watching and simultaneously coding the language portrait. These multimodal transcripts were then coded and analyzed to produce categories and themes emerging from the collected data (e.g., transitioning to university, understandings of what it means to be bilingual, support services at the university and their impact, motivation, factors of attrition, factors of resilience, and the impact of target member communities, among others).

While it is not possible to report on all the cases or data collected as part of the larger study within the limited scope of this paper, the following report focuses specifically on findings stemming from interviews and focus group data related to the second research question: what specific events, practices, and discourses underlie university-level students' experiences and perspectives? In so doing the paper focuses on a key factor that emerged as a powerful force that could shape students' understanding of university-level immersion programs and themselves as language learners: the process of transitioning from high school French language learning programs to university level immersion.

To address this theme and its importance in students' lives, two focal cases are presented to illustrate the complex manner in which university immersion students can interpret the differences noted as they transition from high school French programs to the University of Ottawa French immersion stream. While the two cases that follow are not the only cases where the theme of transitioning to university was addressed, these two cases were selected because of their in-depth and detailed analysis of the experience of transitioning and the importance this had for their lives.

\section{Focal Participants}

Sharon $^{3}$ grew up in an English-majority region in Southern Ontario around Lake Huron where French was rarely if ever heard. Sharon's father's family is from Italy, and Sharon understands Italian but does not speak it. In spite of her exposure to Italian, she self-identified as monolingual English until age 12 after which time she studied French during her last 2 years of elementary school. In high school, she started Late French Immersion. As part of this program, many of the discipline courses that she took were offered completely in French. "Religion, history, mathematics, and all of it was in French"4.

Sandy came from the region of Toronto. She took Core French until her last year of high school but nobody spoke French with her outside of her classes there. School was thus dominated by the use of English. Sandy shared that she would have loved to also learn modern languages other than French, but was forbidden to do so by her parents. This did not, nevertheless, stop her from developing a passion for German after her French high school teacher returned from Germany and told the class about her experiences travelling in that country. Her passion for languages was a key factor in her decision to register both in the University of Ottawa immersion stream and German-language courses.

\section{Findings}

Even though Sharon and Sandy had experienced different types of French language instruction in high school (late French Immersion and Core French), both stressed the 
challenges they had experienced when they transitioned to what they perceived to be an unexpectedly different learning environment at the University of Ottawa. A key difference noted by the students was an increase in the degree to which people were in fact speaking French at the University of Ottawa. Both contrasted this with the more prevalent role English had played in their high school French programs. English was reported to have been used more in their French high school largely because they had studied with English peers who were also fellow French language learners.

In contrast at the University of Ottawa, immersion students are placed in content courses originally designed for and delivered to Francophone students. There is thus direct interaction with Francophones, a feature that is not found in traditional high school French as a second language programs situated in English school boards. In these environments, students' peers are predominantly Anglophones, and contact with French speakers is largely limited to interactions with their French teachers.

Sandy: At high school, so, the only course I had to take was French. And even ... so we spoke a lot of English in class.

Sharon: At home, no one speaks French, it was rather "Franglais." ... We try. The only thing I remember my teacher saying in high school: "Hey! Here we speak French!" [stresses the intonation and laughs]. ... When I came here, what was difficult was ... oral comprehension of my teachers with really strange accents. [Laughs] It was strange to my ears because the French I hear at home is from southwestern Ontario and it's Anglophones who try to speak in French. They are not the Francophones. So, I think this was the biggest challenge.

Students also noted the greater number of opportunities to speak French outside of classroom settings at the University of Ottawa due to its more diverse and plurilingual student body. Sandy for instance pointed out that she could also speak French in residence with her Chinese roommate.

My roommate is French so yeah [Laughs]. That's a pretty big thing actually. I can only speak French with her because she is from China and she can only speak Mandarin and French.

Sharon and Sandy also contrasted the attitudes displayed by high school French teachers versus those of French university instructors. According to them, their teachers had been nicer and more encouraging than the instructors and had been more likely to compliment students' French communication skills rather than simply correct them.

Sharon: I did my work in French in high school, but the teachers were so nice and did not correct me, and they said, "your French is good".

Sharon described the superior level of support she had received throughout her public schooling explaining that in elementary school her Core French teacher had told her parents that she could succeed in high school immersion. Even when Sharon's parents expressed doubts about placing her in late immersion pointing out that no one spoke French in the family, the teacher stressed that Sharon had always received good marks and that she 
obviously had a passion for French. These words of encouragement in addition to the fact that many of her friends were in immersion convinced Sharon and her parents to opt for the late immersion program. Sharon underscored how this type of praise from teachers had contributed to her success in immersion and ultimately her decision to choose to register into a university immersion program, which she qualified as "the best decision I've ever made."

Sandy told a similar story in her interview. She had also received encouragement from her teachers and "good marks" which had fostered her confidence as a core French language learner. She felt since she was "pretty good" in French that she could certainly pursue a university immersion program.

“... in high school, because we only had core French, we would not have extended or immersion, like, I did really really well in my class. [mimicking voice of the teacher] 'Oh my gosh you are so good in French you would be great at the University of Ottawa!' [Switching to her voice] Ok, thank you!"

\section{Addressing the Gap: New Understandings of Themselves as French Language Learners}

The perceived gap between high school French programs and university immersion emerged as a catalyst that led students to re-evaluate their understanding of key elements of their high school experiences. One aspect which was re-evaluated was the degree to which students felt comfortable identifying themselves as strong French language learners. Whereas in high school they had been told that they were good, strong users of French, an assessment of themselves they had accepted and were proud of, it was clear in the students' interviews that this positive self-image was shaken as a result of their experiences in the University of Ottawa immersion French stream.

This sudden decline in students' assessment of themselves as strong French language learners is shown in the following excerpts which contrasts the positive feedback offered by Sharon's high school teachers with her own reassessment of her French proficiency upon entering the University of Ottawa French immersion stream.

Sharon: I did my work in French in high school, but the teachers were so nice and did not correct me and they said, "your French is good, blah blah blah..." Oh! I came here and said, "no, no, no, no, no ... my French is the worst". [She laughs].

This negative downgrading of her French skills was repeated later in the interview as she once again commented on her appraisal of her French abilities after leaving high school.

Interviewer: Did you feel well prepared before you started university?

Sharon: [laughs] NO!, I thought my French was okay but when I got here, I said 'pfeuh'..." I do not know. I do not know anything!" [Laughs] "Help me somebody!

This downgrading of one's French abilities after transitioning to a university-based immersion program was also echoed in Sandy's interview. 
Sandy: Yeah. I remember going into a... again I was already nervous, but after I don't know. I started to listen to different people, meet a lot of people. I realized oh wow a lot of people are bilingual here. Typically, if somebody speaks French at the university, they also speak English and they speak it well. So, it's kind of humbling at the same time... And I got here, and I am, "oh yes," I still have so much more to go. Because in high school when you... I don't know I feel we just did not get pushed as much as we could have. I guess because people are at so many different levels and the teachers are trying to find that balance uh but because I was getting the good marks and I was doing well in my writing assignments... OK, right, I am pretty good here. There is going to be some vocabulary that I don't know. But it turns out that there are still a lot of tenses I don't know yet, there's a lot of terms and sayings that I still have to pick up...

Like Sharon's case, Sandy's original positive assessment of her French was reconsidered and ultimately modified. In high school, her teachers' praise and the fact that she had been a French learner in a world of English speakers explained her decision to join the University of Ottawa and her expectation that she would do well in the immersion stream. However, everything changed as she came into contact with a new environment filled with large numbers of bilinguals who spoke both French and English well and forced her to speak French more frequently. Suddenly confronted with the need to interact daily with native speakers, the level of French that had been deemed adequate in her high school and seen as a point of pride was suddenly no longer adequate nor seen in a positive light. Students' account of their transition thus revealed how a sudden decrease in the amount of support and encouragement by university professors and a new environment filled with strong bilinguals lead to a radical reevaluation of their sense of self as language learners from strong, good language learners ("alright, I am pretty good") to language learners who still have a lot to learn ("It's kind of humbling" ... and "I am really not that great and I need to work harder").

\section{Questioning what a French Language Learning Program Should Be}

In addition to questioning their worth as language learners, interviews with the focal participants also revealed that transitioning to the French immersion stream at the University of Ottawa also impacted their understanding of how French language learning programs might be defined. This phenomenon emerged in both Sandy's and Sharon's interviews. The shock and emotional stress associated with transition to the University of Ottawa French immersion stream was again at the heart of this shift.

Sandy: I found that in high school, I didn't speak French and didn't practice my French, I was only learning it. And then, the difference coming here, is that when you do meet someone who speaks French very fluently, it would be a struggle.

Sharon qualified her transition as one that had been experienced as an emotional shock.

Interviewer: Once in the program at the university, how was your adaptation? When you arrived ... your first semester in French immersion? You said that... 
Sharon: It was a shock. Here, I took my first class, and [short pause] ... after the course I cried. Because I said, "Why am I here? I cannot do it! I travelled eight hours from home to go to school in French! And, why did I do that?" ... I spent one week crying. ... I phoned my father and cried and said, "What am I doing here!"

Sharon's final question in the above excerpt betrays her sense that registering for the French Immersion stream at the University of Ottawa may have been a mistake as she questions her skills and abilities as a French language learner as well as the degree to which her high school French courses adequately prepared her for university-level immersion studies. Sharon even went as far as making a strong distinction between what she characterized as "real" immersion at the University of Ottawa versus the Late French Immersion she had experienced previously "at home."

Sharon: Now [in the University of Ottawa French immersion stream], it's really French immersion. That's what I said when my friends asked me how is French immersion at school here, "Oh, it was not immersion at home, no... here at the University of Ottawa was really the first time that it was real immersion because at home nobody speaks French, it was rather Franglais.

Through her use of the word "real", Sharon makes a powerful statement about her feelings about what she experienced at home. After transitioning to university, her French schooling prior to university is no longer considered an authentic form of French immersion. What happened "at home" in high school is ultimately considered as inauthentic.

\section{Resilience in Spite of a Difficult Transition}

As noted above, findings revealed that students entered university immersion programs with little awareness of the differences that exist between high school French learning environments and the University of Ottawa French immersion stream. This likely reflects efforts by teachers (and university recruiters) to reassure students that they were well equipped and ready to register in a university immersion program. Moreover, the label itself: "Immersion" in the title of the University of Ottawa French stream also presumably encourages students to believe that they are registering for something that will be similar to French learning programs they have come to know in English high school. The findings underscore how important this misconception on the part of the students can be and the degree to which it can lead to feelings of shock, angst, and loss of confidence.

This challenge and ensuing negative reassessment of their abilities as language learners may explain why many students who register for university-level immersion programs do not always remain in these programs for the full duration of their undergraduate degrees. A 2019 University of Ottawa internal report noted that of all the students who registered in the French immersion stream in 2013, five years later, while over $70 \%$ of the student graduated, only $30 \%$ remained in the stream until the end of their

program. In other words, students may graduate, but they do so having failed to complete all of the requirements for them to obtain the immersion diploma. In discussing the difficulties that they had experienced transitioning to university-level immersion, the participants offered valuable insights regarding the forces that could influence students' 
decision to stay or withdraw from a university immersion program, in particular in the early years as they transition from high school.

Similar to other studies of success in academic settings (Kotzé \& Kleynhans, 2013; Salanova et al., 2010), the psychological characteristics of resilience emerged in participants' accounts as core elements that helped students overcome the stress of adjusting to new environments and expectations. For Sharon, for instance, a key factor identified as having helped her was the ability to "keep her core goals in mind" and persevere in the face of adversity.

Sharon: Uh ... and as I said I cried for about a week then after that I said, "No I want to do this! I came here to do this! Put on my big girl pants and try" [determined voice]. I have worked to accomplish this. After the second semester, I took two courses in French again and it was much better. And uh my English classes were ... "fine." It's my mother tongue... All the first year was really a learning curve so ... which is normal.

As such, for Sharon, despite the initial emotional challenge, she displayed a strong desire to follow through on all the work she had already invested in French. Awareness of these past achievements and the need to have them pay off motivated her to remain in the program and try to overcome her difficulties with the belief that they were part of a "learning curve" and that things would improve with time.

Prior case studies of university immersion students (Boettger \& Séror, 2013, Weinberg et al., 2018) validate this belief in the value of giving oneself enough time to adjust and not giving up too early. Findings show that students who can survive the initial difficult transition from high school to university do improve and recover their confidence with time as they begin to identify resources (e.g., writing centres), individuals (e.g., mentors) and strategies (e.g., not translating everything) that can help them overcome the initial challenges of studying in French at a university-level.

In Sandy's case, her explanation of what kept her motivated despite the challenges transitioning to university-level immersion pointed to the power of social interactions with "strong" bilingual as an engine to work harder to match her peers" abilities rooted in her competitive nature

Sandy: I think my motivation to learn French, it's kind of like it really has grown because I desperately want to be bilingual because I am a bit competitive so like I said when I came and I realized that I was not great I was a bit humble and now I really, really want to catch up. So, I want to be able to speak in any language, oh sorry, in either French or English depending on what a person is comfortable with rather than having to be I don't want to say ignorant but be the person who says: "Could you speak English please?" [laughs] just because I feel like when you can speak another person's language they really, really appreciate that."

Sandy's desire to 'catch up' to her peers was not only linked to her sense of her actual language abilities, but also to a specific identity that she wanted to adopt for herself in the future. She sought to be appreciated and seen as a competent and flexible speaker of either French or English. In so doing, others would be comfortable around her no matter their 
mother tongue. She contrasts this identity with what she does not want to be - an individual limited to the use of a single language, a negative state she associates to the word ignorant.

\section{Discussion}

While the case study approach adopted in this paper cannot produce findings that are generalizable to a larger population of university immersion students, the themes highlighted in this article are consistent with the literature on the transition of young adults into university programs and provide useful avenues for future research and pedagogical action.

The findings of this study revealed that transitioning to a French university immersion program is both shocking and uncomfortable and a major catalyst for reshaping French language learners and their language learning. This notion of a difficult transition to university is not new. Stern (1966) proposed that many students approach the transition to university with "a naive, enthusiastic, and boundless idealism concerning its ways and purposes" (p. 411). He stressed that as a result, students were often disappointed when exposed to the conditions of post-secondary studies. Lamoureux (2013) also echoes these findings noting "the importance of ensuring the conditions for a successful transition [from secondary to post-secondary]" especially for "a clientele of great linguistic heterogeneity whose cultural capital differs from that valued in a university setting" (p. 119-120, translated by the authors from French). The focal participants in this article reiterate these principles through their accounts of how their experience of transitioning from high school to university French immersion challenged them and forced them to question and reevaluate their prior experiences as language learners. This could for instance result in no longer identifying past language learning programs as "real" or sufficient preparation for university. The intensity and impact of the shock reported warrant exploring how French programs both in high schools and in universities might better shepherd students into university immersion programs.

This could entail, for instance, providing high school French students with a more detailed and explicit description of the unique nature of university immersion programs. This may be particularly important for students who may interpret the "immersion" label used at the University of Ottawa as a sign of a close continuation of high school language learning circumstances (especially immersion programs). Whichever French learning background students bring to their first year of university, students must be made aware that they are moving towards a very different language learning context than what they have experienced until now in high school. They have to be prepared for what will be a more intense and more immersive language learning situation. They will be confronted with a greater exposure to high-level French speakers, less explicitly supportive instructors, and increased linguistic demands associated with university academic literacies. While there may be a need to better distinguish university versus high school French options, it would nevertheless be also important to discourage students from presenting these differences as evidence that high school programs should be denounced or regretted as ineffective and inauthentic forms of language learning. After all, it is thanks to these programs that students gain the skills and confidence required to believe in their potential to pursue their studies at the post-secondary level in their second official language. The 
crucial role and values of these programs should thus not be underestimated, and students should be encouraged to see their high school French experiences as core and important (if different) steps that are part of their long-term achievement of advanced forms of bilingualism.

Lastly, teams that seek to enhance the support students receive as they transition from high school to university should focus explicitly on how students' identities are challenged and transformed as they enter university immersion programs and are exposed to more direct and frequent contact with the target language community. This could be achieved by organizing information sessions for students. In these sessions, testimonials and videos of university immersion students could be used to launch reflections for instance on the experience of studying with French speakers and the reduced degree of individual support and praise available to students in large lecture courses. Discussions might also raise awareness of the manner in which context can affect one's sense of proficiency in a second language (especially if one enters a community with a greater number of "strong" users of a language). A discussion leader might, for instance, tell future University of Ottawa students:

"When you enter the university program you will be surrounded by Francophones and strong bilinguals. This may make you feel that you are not as good as you once felt. Please understand that the fact that things may feel different and harder, this raising of the bar, is normal and can in fact be a great way to motivate you to go to the next level with your French."

Finally, recommendations emerging from this study include the need to focus on the degree of support offered by professors who teach in university immersion programs. Indeed, while polite, and thus never stating it explicitly, students' narratives demonstrate the importance placed on encouragement and praise of their efforts as language learners by their instructors. Undoubtedly, many university content instructors feel that it not their place to support (or praise) language learning (Leask, 2015). Yet, the findings presented underscore the importance of considering the impact that this pedagogic stance can have on language learners' ultimate investment and motivation. It should be remembered that taking content courses delivered exclusively in French remains above all an optional choice for University of Ottawa immersion students. In other words, they are deliberately adding a level of difficulty to their studies that can be removed by simply switching out of the University of Ottawa French immersion stream and opting for the simpler path of completing their studies in English. If we are serious about encouraging students to pursue post-secondary studies in French, we must ensure that in spite of the literacy gaps these students experience when they enter university, they continue to feel encouraged and supported by the professors and instructors who are interested and happy to work with them. Findings suggest this is particularly important in students' first year in the University of Ottawa French immersion stream, a moment filled with stress and self-doubt (Morton et al., 2014; Pancer, et al., 2004; Stern, 1966). 


\section{Conclusion}

Many factors impact the students' dynamic and constantly evolving understanding of what it means to choose to continue to pursue French at a university-level. Our findings confirm that the awkward and uncomfortable transition from high school French to a university French immersion stream occurs at a time when prior positive identities as strong language learners can be displaced by a sense of weakness and discomfort. As students come to a new stage in their L2 development, they are forced to re-examine their actions as language learners, their motivation, and the identities associated with these practices. Universities and high schools must thus work together to counteract the negative identities and perceptions that can result from these processes. Perhaps most importantly students must be reassured that choosing to continue to study French in university despite its challenges is not a mistake. They are simply at the start of something very different. Universities and high schools must therefore not only improve students' language proficiency they must also support students at a socio-affective level. Language learning, seen as an engine of identity (de/re)construction (Norton, 2013) will always imply moments of discomfort, doubt, and uncertainty. Left alone to manage these feelings, many students may well decide not to continue with a process that undermines (at first) their sense of self. Resilience, maturity, a goal-oriented perspective, and an appreciation of the value of the investment one has already made in French are all factors that can be deployed to keep students motivated and engaged. As such, these periods of transition must be acknowledged as unique moments primed to force students to review and transform their goals, their views of language skills, and their relationships with fellow speakers of French. Other key moments of transition in students' trajectories as university language learners could also be investigated especially students' transition to graduate studies and professional careers.

Correspondence should be addressed to Jérémie Séror

Email: jseror@uottawa.ca

\section{Notes}

${ }^{1}$ English Medium Instruction (or English Medium Education) is another popular form of additional language education found in some university contexts (Dafouz \& Smit, 2014; Doiz et al., 2011). It should be noted however that these programs typically do not offer language support and simply teach content through the language. For these reasons, we do not include this approach as a form of content-based education which would have a more explicitly focus and integration of language skills development in addition to disciplinary knowledge development.

${ }^{2}$ Core French programs are traditional language courses offered at the elementary and secondary level in Canadian schools for a few hours a week. It is the most popular program in Canada, with 90\% enrollment in this approach. Intensive French usually offered in Grades 5 or 6 offer a more sustained form of language instruction, with more teaching hours and a more communicative approach.

3 The name of the participants in order to protect their identity and privacy. 
${ }^{4}$ Quotations in italics refer to data which was translated from French.

\section{References}

Antoniadou, V. (2017). Collecting, organizing and analyzing multimodal data sets: The contributions of CAQDAS. In E. Moore \& M. Dooly (Eds.), Qualitative approaches to research on plurilingual education (pp. 435-450). Researchpublishing.net.

Auger, J. (2002). French immersion in Montreal: Pedagogical norm and functional competence. In K. Bardovi-Harlig, S. Gass, S. Magnan \& J. Walz (Eds.), Pedagogical norms for second and foreign language learning and teaching (pp. 81-101). John Benjamins.

August, D., Shanahan, T., \& Shanahan, L. (2006). Developing literacy in second-language learners: Report of the National Literacy Panel on Language Minority Children and Youth. Lawrence Erlbaum Assoc Inc.

Bemporad, C., \& Vorger, C. (2014). « Dessine-moi ton plurilinguisme »: analyses de dessins entre symbolisation et réflexivité. GLOTTOPOL: Revue de sociolinguistique en ligne 24, 122-140.

Boettger, A., \& Séror, J. (2013). "Plus dur que je ne l'aurais cru!" : Les hauts et bas d'une participation au Régime d'immersion en français. Paper presented at the Symposium du programme d'initiation à la recherche au premier cycle, Université d'Ottawa.

Brinton, D., Snow, M. A., \& Wesche, M. B. (2003). Content-based second language instruction. University of Michigan Press.

Burger, S., \& Chrétien, M. (2001). The development of oral production in content-based second language courses at the University of Ottawa. Canadian Modern Language Review/La Revue canadienne des langues vivantes, 58(1), 84-102.

Burger, S. \& Weinberg, A. (2014). Three factors in vocabulary acquisition in a university French immersion adjunct context. Journal of Immersion and Content-Based Language Education, 2 (1), 23-52.

Burger, S., Weinberg, A., \& Wesche, M. (2013). Immersion studies at the University of Ottawa: From the 1980s to the present. Cahiers de l'ILOB, 6, 21-43.

Byrnes, H. (2006). Advanced language learning: The contribution of Halliday and Vygotsky. Continuum.

Cammarata, L. (Ed.) (2016). Content-based foreign language teaching. Routledge.

Cammarata, L., \& Tedick, D. J. (2012). Balancing Content and Language in Instruction: The Experience of Immersion Teachers. The Modern Language Journal, 96(2), 251-269.

Canagarajah, A. S., \& Jerskey, M. (2009). Meeting the needs of advanced multilingual writers. In R. Beard, D. Myhill, J. Riley, \& M. Nystrand (Eds.), The SAGE handbook of writing development (pp. 472-488). Thousand Oaks, CA: Sage Publications.

Casanave, C. P. (2002). Writing games: Multicultural case studies of academic literacy practices in higher education. Lawrence Erlbaum Associates, Publishers. 
Castellotti, V., \& Moore, D. (2009). Dessins d'enfants et constructions plurilingues. Territoires imagés et parcours imaginés. In M. Molinié (Ed.), Le dessin réflexif. Élément pour une herméneutique du sujet plurilingue (pp. 45-85). Centre de Recherche Text Francophonies (CRTF) - Encrages, Belles Lettres.

Cenerelli, B. B., Lemaire, E., \& Mougeon, F. (2016). Visages multiples de l'immersion au Canada: de la mission à la réalité. In H. Knoerr, A. Weinberg, \& A. GohardRadenkovic (Eds.), L'immersion française à l'université : Politiques et pédagogies (pp. 121-160). Les presses de l'Université d'Ottawa,.

Cheng, Y.-H. (2014). Dissertation grant proposals as "writing game": An exploratory study of two L2 graduate students' experiences. English for Specific Purposes, 36, 74-84.

Courcy, M. D. (2002). Learners' experiences of immersion education: Case studies of French and Chinese. Multilingual Matters.

Dafouz, E., \& Smit, U. (2014). Towards a dynamic conceptual framework for Englishmedium education in multilingual university settings. Applied Linguistics, 37(3), 397-415.

Dalton-Puffer, C. (2011). Content-and-language integrated learning: From practice to principles? Annual Review of Applied Linguistics, 31 (1), 182-204.

Doiz, A., Lasagabaster, D., \& Sierra, J. M. (2011). Internationalisation, multilingualism and English-medium instruction. World Englishes, 30(3), 345-359.

Duff, P. (2007). Second language socialization as sociocultural theory: Insights and issues. Language Teaching, 40 (04), 309-319.

Duff, P. A. (2010). Language socialization into academic discourse communities. Annual Review of Applied Linguistics, 30 (1), 169-192.

Duff, P. A., \& Anderson, T. (2015). Academic language and literacy socialization for second language students. In N. Markee (Ed.), The handbook of classroom discourse and interaction (pp. 337-352). John Wiley \& Sons.

Duff, P. A., \& Talmy, S. (2011). Language socialization approaches to second language acquisition. In D. Atkinson (Ed.), Alternative Approaches to Second Language Acquisition (pp. 95-116). Routledge.

Fraser, G. (2016). L'immersion: naissance et évolution d'un concept canadien. In $\mathrm{H}$. Knoerr, A. Weinberg, \& A. Gohard (Eds.), L'immersion française à l'université : Politiques et pédagogie (pp. v-xix). Les presses de l'Université d'Ottawa

Genesee, F. (2004). What do we know about bilingual education for majority-language students? In T. K. Bhatia \& W. Ritchie (Eds.), The Handbook of Bilingualism and Multilingualism (pp. 547-576). Blackwell.

Genesee, F., \& Lindholm-Leary, K. (2013). Two case studies of content-based language education. Journal of Immersion and Content-based Language Education, 1(1), 333.

Gohard-Radenkovic, A. (2016). Cheminements réflexifs d'étudiants du Régime d'immersion en français sur leurs parcours et leurs cheminements. In H. Knoerr, A. Weinberg, \& A. Gohard (Eds.), L'immersion française à l'université : Politiques et pédagogie (pp.447-465). Les presses de l'Université d'Ottawa

Government of Canada. (2018). Action Plan for Official Languages - 2018-2023: Investing in Our Future. https://www.canada.ca/en/canadian-heritage/services/officiallanguages-bilingualism/official-languages-action-plan/2018-2023.html 
Hermanto, N., Moreno, S., \& Bialystok, E. (2012). Linguistic and metalinguistic outcomes of intense immersion education: How bilingual? International Journal of Bilingual Education and Bilingualism, 15 (2), 131-145. http://doi.org/10.1080/13670050.2011.652591

Knoerr, H., Weinberg, A., \& Gohard-Radenkovic, A. (Eds.). (2016). L'immersion française à l'université: Politiques et pédagogies. Les presses de l'Université d'Ottawa.

Knoerr, H. \& Weinberg, A. (2013) Podcasts on listening and note-taking strategies for French immersion students at university level: from design to impact assessment. Les cahiers de l'ILOB, 5, 71-84.

Kotzé, M., \& Kleynhans, R. (2013). Psychological well-being and resilience as predictors of first-year students' academic performance. Journal of Psychology in Africa, 23(1), 51-59.

Kramsch, C. (Ed.) (2002). Language acquisition and language socialization: Ecological perspectives. Continuum.

Krueger, R. A. (2015). Focus groups: A practical guide for applied research (5th ed.). Sage publications.

Lambert, W. E., \& Tucker, G. R. (1972). The bilingual education of children: The St. Lambert experiment. Newbury House.

Lamoureux, S. (2013). L'expérience étudiante au Régime d'immersion en français: perspectives et constats. Cahiers de L'ILOB / OLBI working papers, 6, 109-121.

Lantolf, J. P., Thorne, S. L., \& Poehner, M. E. (2015). 207-226. (2015). Sociocultural theory and second language development. Theories in second language acquisition: An introduction.

Lazaruk, W. (2007). Linguistic, academic, and cognitive benefits of French immersion. Canadian Modern Language Review/La Revue canadienne des langues vivantes, 63(5), 605-627.

Leask, B. (2015). Internationalizing the curriculum. Routledge.

Lemaire, E. (2013). Étudier à l'université en français dans le contexte minoritaire ouestcanadien: ce que peut nous apprendre le dessin réflexif. Les cahiers de l'ILOB, 6, 87-107.

Lindholm-Leary, L., \& Borsato, G. (2006). Educating English language learners: A synthesis of empirical evidence. In F. Genesee, K. Lindholm-Leary, W. Saunders, \& D. Christian (Eds.), Academic achievement (pp. 176-222). Cambridge University Press.

Lyster, R. (2008). Evolving perspectives on learning French as a second language through immersion. In D. Ayoun (Ed.), Studies in French Applied Linguistics (pp. 3-36). John Benjamins.

Lyster, R. (2015). Using form-focused tasks to integrate language across the immersion curriculum. System, 54(Supplement C), 4-13.

Lyster, R., \& Tedick, D. J. (2014). Research perspectives on immersion pedagogy: Looking back and looking forward. Journal of Immersion and Content-based Language Education, 2(2), 210-224.

Macintyre, P. D., Burns, C., \& Jessome, A. (2011). Ambivalence about communicating in a second language: A qualitative study of French immersion students' willingness to communicate. The Modern Language Journal, 95(1), 81-96. 
Mady, C. (2017). The bilingual advantage for immigrant students in French immersion in Canada: linking advantages to contextual variables. International Journal of bilingual education and bilingualism, 20(3), 235-251.

Marsh, D., \& Frigols Martín, M. J. (2012). Content and Language Integrated Learning. In C. A. Chapelle (Ed.), The Encyclopedia of Applied Linguistics (pp. 911-920): Wiley-Blackwell.

Marshall, S., \& Laghzaoui, G. (2012). Langues, identités et francophonie chez des étudiants universitaires issus de l'immersion française à Vancouver, au Canada. Canadian Modern Language Review/La Revue canadienne des langues vivantes, 68(2), 216-233.

Mejía, A. D. (2008). Researching developing discourses and competences in immersion classrooms In N. Hornberger (Ed.), Encyclopedia of Language and Education (Vol. 10, pp. 3412-3423): Springer.

Merriam, S. B. (1998). Qualitative research and case study applications in education (2nd ed.). Jossey-Bass Publishers.

Molinié, M. (2009). Le dessin réflexif : élément d'une herméneutique du sujet plurilingue. CRTF-Encrage, Belles Lettres.

Moore, D., Marshall, S., \& Zhu, Y. (2015). Plurilinguismes et identités à l'université. Les inter-maillages du français, du chinois et de l'anglais chez des étudiants de première année à Vancouver au Canada. In B. Bouvier-Laffite \& Y. Loiseau (Eds.), Polyphonies franco-chinoises: Mobilités, dynamiques identitaires et didactique (pp. 81-100). L'Harmattan.

Morita, N. (2009). Language, culture, gender, and academic socialization. Language and Education, 23(5), 443-460

Morita, N., \& Kobayashi, M. (2008). Academic discourse socialization in a second language. In P. A. Duff \& N. Hornberger (Eds.), Language socialization: Encyclopedia of language and education (Vol. 8, pp. 244-255). Springer.

Morton, S., Mergler, A., \& Boman, P. (2014). Managing the transition: The role of optimism and self-efficacy for first-year Australian university students. Journal of Psychologists and Counsellors in Schools, 24(1), 90-108.

Ninnes, P., \& Hellstén, M. (2005). Internationalizing higher education: Critical explorations of pedagogy and policy. CERC Studies in Comparative Education. Springer.

Norton, B. (2013). Identity and language learning: Extending the conversation. Multilingual matters.

Ochs, E., \& Schieffelin, B. (2008). Language socialization: An historical overview. In P. A. Duff \& N. H. Hornberger (Eds.), Language socialization: Encyclopedia of language and education. (2nd ed., Vol. 8, pp. 3-15). Springer.

Office of the Commissioner of Official Languages. (2009). Annual report 2008-2009 Two official languages, one common space: 40th anniversary of the official languages act.

file://C:/Users/Alysse/Downloads/Canada_OM\%20Official\%20Languages_Annual \%20Report_2008_2009_EN.pdf

Pancer, S. M., Pratt, M., Hunsberger, B., \& Alisat, S. (2004). Troubled waters: Helping students make the transition from high school to university. Guidance \& Counselling, 19(4), 184-190. 
Parmeggiani, P. (2009). Going digital: Using new technologies in visual sociology. Visual Studies, 24 (1), 71 - 81.

Salanova, M., Schaufeli, W., Martínez, I., \& Bresó, E. (2010). How obstacles and facilitators predict academic performance: The mediating role of study burnout and engagement. Anxiety, stress \& coping, 23(1), 53-70.

Saul, J. R. (2009, April 30th - May 1st, 2009). Confronting a Canadian affliction: Refusal to accept bilingualism as normal. Paper presented at the CCERBAL Conference: Language Immersion as Formal and Informal Learning, University of Ottawa, Ottawa.

Schleppegrell, M., \& Colombi, C. (2002). Developing advanced literacy in first and second languages: Meaning with power. Lawrence Erlbaum Associates.

Séror, J., \& Weinberg, A. (2012). Construction identitaire et linguistique : le régime d'immersion en français de l'Université d'Ottawa. Synergies Europe, 7, 215-230.

Smit, U., \& Dafouz, E. (2012). Integrating content and language in higher education: An introduction to English-medium policies, conceptual issues and research practices across Europe. AILA Review, 25, 1-12.

Stern, G. G. (1966). Myth and reality in the American college. AAUP Bulletin, 52 (4), 408414.

Swain, M., \& Johnson, R. K. (1997). Immersion education: A category within bilingual education. In R. K. Johnson \& M. Swain (Eds.), Immersion education: International perspectives (pp. 1-16). Cambridge University Press.

Tedick, D. J., Christian, D., \& Fortune, T. W. (2011). Immersion education. Practices, policies, possibilities. Multilingual Matters.

Weinberg, A., Séror, J., \& Simonet, T. (2018). Sur la piste des facteurs d'attrition et de rétention au sein du Régime d'immersion en français à l'Université d'Ottawa. Revue canadienne des langues vivantes / Canadian Modern Language Review, 74(2), 302330.

Wesche, M., \& Skehan, P. (2002). Communicative, task-based, and content-based language instruction. In R. Kaplan (Ed.), The Oxford handbook of applied linguistics (pp. 207-228). Oxford University Press.

Wilkinson, R., \& Walsh, M. L. (Eds.). (2015). Integrating Content and Language in Higher Education: From Theory to Practice Selected papers from the 2013 ICLHE Conference, Frankfurt-am-Main: Peter Lang.

Woods, D. K., \& Dempster, P. G. (2011). Tales from the bleeding edge: The qualitative analysis of complex video data using Transana. Forum: Qualitative Social Research, 12(1).

Yazan, B. (2015). Three approaches to case study methods in education: Yin, Merriam, and Stake. The qualitative report, 20(2), 134-152.

Yin, R. K. (2014). Case study research: Design and methods (5th ed.). Thousand Oaks, CA Sage.

Zappa-Hollman, S., \& Duff, P. A. (2015). Academic English socialization through individual networks of practice. TESOL Quarterly, 49 (2), 333-368. 


\section{Appendix A}

Breakdown of participants' French Language Learning Experiences in High School

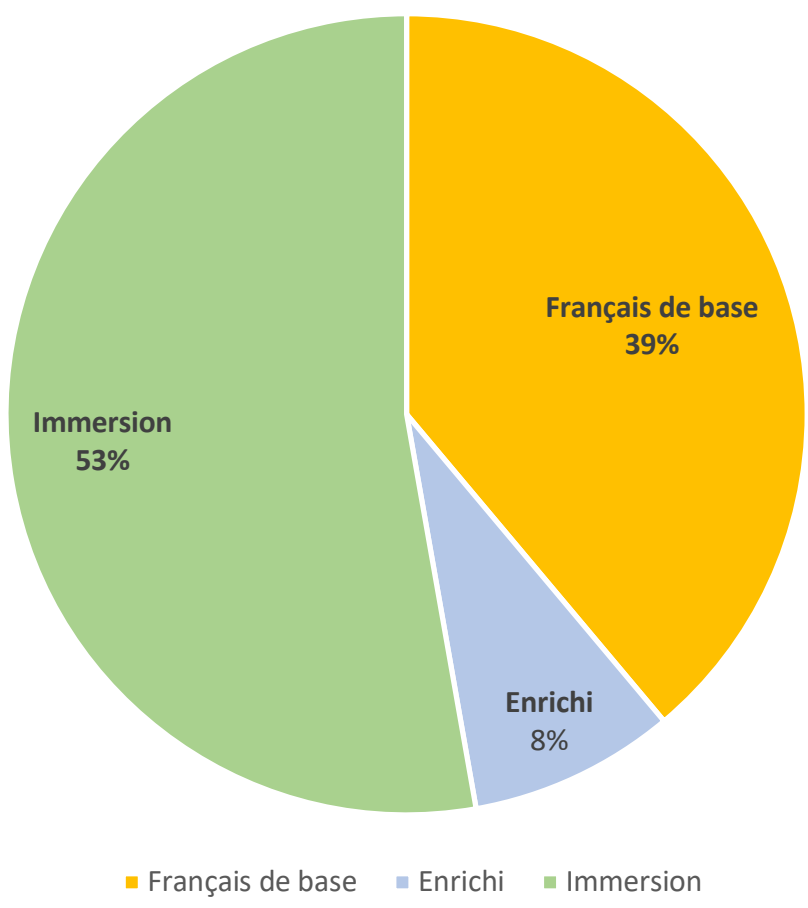




\section{Appendix B \\ Sample Interview Guide (Spring 2018)v}

\section{Progrès en français}

a. Comparé à il y a 3 ans, comment évalueriez-vous votre français? Qu'est-ce qui est mieux ou pareil?

i. Si vous percevez une amélioration?

1. Quelles sont les preuves de celle-ci? Qu'est-ce qui vous mène à dire que.....
a. Preuves écrites
b. Preuves académiques
c. Preuves ami(e)s
d. Preuves réussites
e. Preuves professionnelles

2. Test de pour le certificat de compétence en langue seconde

a. L'avait vous passé?

b. Comment percevez-vous ce test?

i. Désiré, valeur, utile?

c. Résultat obtenu?

d. Est-ce que ceci sera un atout pour votre entrée sur le marché du travail?

3. Attrition et rétention

a. Cette année, avez-vous pensé à quitter le programme d'immersion? Si oui pourquoi? Si non, pourquoi pas?

b. Connaissez-vous des gens qui ont quitté le programme? Qu'est-ce qui les a poussés selon vous à prendre cette décision?

4. Avantages du programme tel que vous le percevez?

5. Désavantages du programme tel que vous le percevez?

6. Choses à améliorer/Recommandations suite à vos expériences?

7. Conseils pour de futurs étudiants

a. Qu'est-ce qui fait la différence?

b. Comment rester motiver / Comment ne pas se décourager?

c. Stratégies importantes?

d. Cours à prendre absolument?

e. Cours à éviter?

8. Conseils pour l'administration du programme

a. Services importants?

b. Expériences importantes?

i. Voyage à l'étranger

1. Est-ce quelque chose que vous avez incorporé dans votre programme d'étude (pourquoi ou pourquoi pas?)

2. Est-ce quelque chose qui devrait être obligatoire pour les étudiants du RIF?

c. Éléments à rajouter au programme?

i. Cheminement / cours obligatoire vs cours facultatifs (ex. un cours d'écriture obligatoire)?

d. Éléments à éliminer dans le programme? 
${ }^{v}$ In the third year of the study, to encourage students, French language development, questions were asked in French, but at all stages of the data collection, students could ask to have the question repeated in English and were allowed to answer in the language of their choice. 